\title{
Technology-Based Recruitment and Selection Approaches of an American Multinational Company (AMNC): Practical Implications
}

\author{
Mussie T. Tessema (Corresponding author) \\ Dept. of Business Administration, Winona State University \\ PO Box 5838, Winona, MN 55987, USA \\ Kiflemariam Abraham \\ School of Business, Catholic University of Eastern Africa \\ P O Box 62157, Nairobi, Kenya
}

Jing Han

Dept. of Business Administration, Winona State University

PO Box 5838, Winona, MN 55987, USA

Madison Bowe

Dept. of Business Administration, Winona State University

PO Box 5838, Winona, MN 55987, USA

Tayler Bug

Dept. of Business Administration, Winona State University

PO Box 5838, Winona, MN 55987, USA

Received: May 24, 2020 Accepted: June 28, 2020 Online published: July 27, 2020

doi:10.5296/ijhrs.v10i3.17082ＵRL: https://doi.org/10.5296/ijhrs.v10i3.17082 


\section{Abstract:}

This study identifies and discusses six technologies that affect recruitment and selection approaches using an American multinational company (AMNC) as a case study. It indicates that technology-based recruitment and selection approaches have had a noticeable impact on the AMNC's recruitment and selection processes and practices in general, and the three stakeholders (human resource- HR- managers, hiring managers, and job-applicants) in particular. It concludes that the use of technology-based recruitment and selection approaches is not the matter of choice but is a requirement for the success of any company. It also offers the study's implications and future research directions.

Keywords: recruiting, selection, e-recruiting, e-selection, human resource (HR), technology, $\mathrm{MNC}$

\section{Introduction}

It is generally believed that organizational workforce is the most important resource that provides companies a competitive advantage (Barney, 1991; Marler \& Parry, 2015). As a result, companies continue to wage the 'war for talent' (Lavelle, 2003), which has also increased both the scope and complexity of attracting and acquiring talented workforce (Feffer, 2017; Ployhart, 2006). The realities of today's labor market prompt companies to use innovative tools to attract and select the best and the brightest employees. One-way companies can use innovative tools to attract and select talent is the adoption of technologies (e.g., Internet, computer, HR software, social media, HR analytics, algorithm, gamification of recruitment, recruitment chatbot, \& smart device applications) in recruitment and selection practices (Bersin, 2017; Dineen \& Noe, 2009; Fleck, 2016; Kuncel, Ones \& Klieger, 2014; Phillips, 2020; Shah, 2004; Wright, 2018). Simply put, the two HR functions, which have been significantly impacted by technology are recruitment and selection approaches and practices.

Recruitment and selection approaches have been rapidly changing mainly because of advances in digital technology. The use of technology in recruitment and employee selection can allow the three main stakeholders (HR managers, hiring managers, and online job-applicants) access to HR related information and services through the Internet (Dineen \& Noe, 2009; Lengnick-Hall \& Moritz, 2003). The use of technology for recruitment and selection purposes is a requirement especially given the rise of Millennials, who will comprise more than half of the US workforce by 2020 (Jackson, 2016). Technology-based recruitment and selection approaches offer strong competitive advantages, and without an agile way to incorporate new HR technology, a company could be at an extreme disadvantage (Phillips, 2020; SHRM, 2016). Vendors have introduced disruptive and incredible new technologies in recruitment and selection, as will be discussed. Thus, one can argue that the adoption of technology for recruitment and selection evolves from nice-to-have to must have.

Although many studies have been conducted on technology-based recruitment and selection approaches, only limited research has focused on the types of technologies that impact recruitment and selection approaches in general and the three stakeholders (HR managers, 
hiring managers, and online job-applicants) in particular. This study, therefore, addresses this research gap by using an American multinational company as a case study.

\section{Research objective}

This study intended to answer the following four research questions:

1. What types of technologies affect recruitment and selection approaches?

2. What are the advantages and limitations of the use of technology-based recruitment and selection approaches?

3. What types of technology-based recruitment and selection approaches are adopted by the American multinational company?

4. What are the study's implications and future research directions?

\section{Literature Review}

Recruitment and selection are two HR functions, which play an important role in building an organizational workforce (Breaugh, 2013; Heneman, Judge, \& Kammeyer-Mueller, 2019; Tessema et al., 2017). While recruitment is the process of generating a pool of qualified job applicants for organizational jobs (Mathis, Jackson, Valentine \& Meglich, 2017, p. 200), selection is the systematic process of deciding which applicants to hire (Lepak \& Gowan, 2020 , p. 234). Recruitment and selection decisions influence everything from organization strategy, to the extent it is able to compete and win in the highly competitive marketplace (Bondarouk, Parry, \& Furtmueller, 2017; Phillips, 2020). Until the early 1990s, recruitment and selection were very manual processes.

Technology-based recruitment and selection approaches, in this study, refer to various forms of technology used to recruit potential job applicants to fill jobs and assess the degree to which job applicants' knowledge, skills, abilities, and other characteristics fit with the job requirements and the company. That is, they refer to the application of internet, computers, and telecommunication devices to attracting, assessing, and selecting applicants who fit the job and the company (Stone, Deadrick, Lukaszewski, \& Johnson, 2015). Technology does not only play a key role in attracting potential job applicants to fill jobs in a company but also in assessing and selecting the most qualified applicants. Prior studies suggest that technology has had significant impact on recruitment and selection approaches and processes (Breaugh, 2013; Pfieffelmann, Wagner, \& Libkuman, 2010; Tufts, Jacobson, \& Stevens, 2014; Phillips, 2020). Thus, this study argues that the use of technology is a sine qua non for hiring employees who best fit not only the job but also the company (Campos, Arrazola, \& Hevia, 2017; SHRM, 2016) and has a significant impact on the three stakeholders of recruitment and selection approaches, who were identify by Heneman et al. (2019), namely, HR managers, hiring managers, and job-applicants.

\subsection{Types of Technologies That Affect Recruitment and Selection Approaches and Practices}

As previously indicated, by technology-based recruitment and selection approaches, we are referring to any tool that influence the way companies recruit and select qualified applicants. Since the mid-1990s, the number of technology-based recruitment and selection approaches has increased considerably. Although there are many studies on acceptance and attractiveness 
of technology-based recruitment and selection approaches (e.g., Allen, Mahto, \& Otondo, 2007; Chapman \& Webster, 2003; Stone \& Lukaszewski, 2009), little is known by the academic community about the range of technologies being used to recruit and select "the best and brightest employees." Emerald (2013) states that there are several tools that have improved the performance of recruitment and selection practices with minimal human interaction. Bersin (2017) also reports that technology has provided companies with many new tools for managing their recruitment and selection activities. Hence, there are many technologies and platforms that significantly impact recruitment and selection practices. While a detailed review of research on technologies that influence recruitment and selection processes is beyond the scope of this study, this section provides an overview of six technologies that positively influenced recruitment and selection approaches and processes.

- Job boards: While job boards enable organizations to post job ads through the help of the internet, they enable potential job applicants to search job openings and submit their résumés to organizations for review (Parry \& Wilson, 2009). Job boards can be of different types such as corporate job boards (e.g., organizational employment websites), commercial job boards (e.g., Indeed, CareerBuilder, \& Monster), and niche job boards (e.g., CollegeRecruiter.com \& Dice.com).

- Recruiting software: Many recruiting software (e.g., UltiPro, iCIMS recruit, LinkedIn Talent, SmartRecruiters, Jobvite, SkillSurvey, Zoho Recruit, \& Greenhouse) are used in recruitment and selection efforts. Recruiting software addresses talent acquisition needs and efficiently manage the entire recruitment and selection processes. They enable HR professionals to keep track of all job requisitions, manage job applicants' profiles and resumes, and exchange candidate feedback, all from one single location (Campos et al., 2017; Dineen \& Allen, 2013). They can search for resumes internally and externally, oversee interview schedules, and integrate job boards into their overall HR and recruiting functions (Bersin, 2017; Phillips, 2020). For example, an applicant tracking system is a software application that enables the electronic handling of recruitment needs.

- Social media: It has become one of the most common recruiting methods. Social media is a powerful tool in the job search (Glassdoor, 2016; El Ouirdi, El Ouirdi, Segers, \& I Pais, 2016; Melanthiou, Pavlou, \& Constantinou, 2015; Ollington et al., 2013; SHRM, 2017; Vitale, 2016). There are many social media channels used for recruiting purposes (e.g., LinkedIn, Facebook, Twitter, Instagram, \& Pinterest). The three top social sites used for recruiting are LinkedIn (96\%), Facebook (66\%), and Twitter (53\%) (SHRM, 2017). With the increasing number of U.S. Internet users on social media, the above social media channels have become more and more popular for employer communication and recruitment. The number of jobseekers who save a job from their mobile device and later apply to the job on a desktop has increased significantly (Glassdoor, 2016).

- Interactive technologies: They have had significant impact on recruiting and selection processes. They may include Web 2.0, virtual reality, social media, blogs, 


\section{Macrothink}

International Journal of Human Resource Studies

ISSN 2162-3058

2020, Vol. 10, No. 3

and virtual job previews (Dineen \& Allen, 2013; Stone et al., 2015). There are different types of video interviews: one-way, two-way, live, and pre-recorded, and the benefits may vary depending on the type of video interview (Phillips, 2020). According to Phillips (2020), there are three ways that interactive video is modernizing recruitment and selection efforts: Capturing job applicants' attention, engaging diverse audiences, and measuring the impact of recruiting content.

- Game simulation or gamification of recruitment: It is one of the new innovations that has greatly influenced recruitment and selection practices (Bersin, 2017; Zielinski, 2015). Gamification can stir people's interest in job openings, project an innovative image of an employer and deliver accurate previews of applicants' future job performance (Zielinski, 2015). Some recruiting games introduce candidates to careers they may not otherwise have considered, while giving job applicants a realistic preview of the job (Feffer, 2017; Zielinski, 2015). Many companies have been using different types of games for recruitment and selection purposes. Gamification is part of an ongoing shift toward more-interactive talent acquisition strategies (Fleck, 2016; Phillips, 2020).

- HR analytics: It is the use of data and data analysis techniques to understand, improve, and optimize the people side of business (Dearborn \& Swanson, 2017). It helps predict which job applicants are likely to be successful employees or employees who are less likely to quit (Feffer, 2017; Kuncel et al., 2014). Google is a pioneer in using HR analytics to create a better workforce. In 2009, Google assembled a team of scientists, consultants, and technologists to create algorithms that would identify which candidates were most likely to succeeded. Since then many companies have been using HR analytics to measure performance, identify behavioral patterns and bring in the right people based on these pattern (Fleck, 2016, p. 132).

\subsection{Advantages and Limitations of Technology-Based Recruitment and Selection Approaches}

Prior studies have identified numerous advantages and limitations of technology-based recruitment and selection approaches, as shown in Tables 1 and 2.

Table 1. Advantages of technology-based recruitment and selection approaches

\section{No. Advantages How}

1 Cost *. By saving costs that would have been paid for traditional recruitment reduction approaches, which

are held at massive events such as tours and recruiting events (Hubbard \& Loos, 2013;

Johnson \& Gueutal, 2011).

*. By improving the efficiency of recruitment and selection approaches (Buckley, Minette,

Joy, \& Michaels, 2004; Hubbard \& Loos, 3013).

*. By decreasing organizational dependency on external agencies such as 
newspapers and

recruitment agencies (Emerald, 2013; Feffer, 2017).

2 Increased the number of job applicants

*. By broadening the scope for job applicants, who can easily access the jobs and contacting

the employers at the same time (Wright, 2018; Weber, 2012).

*. By reaching passive jobseekers without geographical limits (Breaugh, 2013; Holm, 2010).

*. By enhancing and simplifying the candidate search (Marler \& Parry, 2015; Glassdoor, 2016).

3 Easier *. By reducing the administrative burden and providing better tools for the administration recruitment team

(Marler \& Parry, 2015; Mathis et al., 2017).

$*$. By improving the recruitment process and boosting candidate confidentially (Pandre, 2011;

Tong, 2009).

*. By streamlining the process of collecting and screening résumés (Cappelli, 2001).

4 Improved the *. By reaching wider areas, which in turn improves the chance of finding the quality of right people

applicants (Gravili, 2003; Kavanagh \& Johnson, 2018).

*. By developing a strong candidate pool through brand and relationship management $(A l$ -

Khanak \& Mahmood, 2014; Maurer, 2017).

*. By efficiently managing the selection process of identifying the best job applicants (Breaugh,

2013; Marler \& Parry, 2015).

Table 2. Limitations of technology-based recruitment and selection approaches

No. Limitations

1 Being impersonal and one-way communication (Chapman \& Webster, 2003; Emerald, 2013; Johnson \& Gueutal, 2011; Stone et al., 2015),

2 Attracting large volume of job applications, many of which from unqualified applicants (Mathis et al., 2017; Stone et al., 2005; Weber, 2012),

3 Have adverse impact on minorities who are less likely to have internet proficiency and internet connection (Heneman et al., 2019; Pandre, 2011).

Although technology-based recruitment and selection approaches have had some limitations, recently, many of them have become more information-rich, interactive, and interpersonal, which in turn are more likely to minimize the above stated limitations (Badger et al., 2014; Kavanagh \& Johnson, 2018; Wright, 2018; Zielinski, 2016). 


\section{Research Methodology}

\subsection{Research Design}

This study used a case study design. Yin (1994) describes four alternative research designs: case study, survey, experiment, and analysis of archival information. According to Yin (1994), the decision to use one of these approaches depends on the following three issues: The type of the research question, the control that a researcher has over actual behaviour events, and the focus on contemporary as opposite to historical phenomena. Yin (1994) suggests that a case study is preferred where, the research question to be addressed is of the type of 'how-why,' when control of the researcher over the research is non or very insignificant and the focus is on a contemporary phenomenon within a real-life context. A case study design allows researchers to study processes in their social context (Eisenhardt, 1989; Siggelkow, 2007). A case study design deemed to be appropriate for the current study and technology-based recruitment and selection approaches are used as the unit of analysis.

\subsection{Sampling Technique Used and the Types of Data Collected}

This study used a purposive sampling, which is a sampling technique that depends on the judgement of the researcher when choosing who to ask to participate (Eisenhardt, 1989). Researchers may implicitly choose a 'representative' sample to suit their needs, or approach individuals with certain characteristics (Lichtman, 2014). In this study, nine in-depth interviews were conducted with three HR managers, three hiring managers, and three employees who were hired via technology-based recruitment and selection approaches. Gender wise, two of the three HR managers were female, one of the three hiring managers was female, and one of the three employees hired via technology-based recruitment and selection approaches was female. Department wise, three of the nine interviewees were from the HR Department, two of them were from the Accounting Department, two of them were from the Marketing Department, and two of them were from the IT department. Regarding to their work experience, while sixty-seven percent of them had four to thirty-two years of work experiences, thirty-three percent of them had one to three years of work experiences. The data used in this study were collected through semi-structured interviews and were predominantly qualitative. Qualitative data was considered to be more suitable, since it can provide insights into complex social processes (Creswell, 2011). We believed that conducting nine in-depth interviews can be sufficient to reach a reasonable degree of saturation, in that, less new information was collected, the more interviews that were conducted; in qualitative research, saturation is an important criterion to determine the number of interviews required (Ezzy, 2002). To ensure confidentiality of the collaborating American multinational company and the respondents (interviewees), the company in this study has been given a fictitious name: American Multinational Company (hereafter refers to "AMNC"). AMNC is among top seventy in Forbes' 2017 listing of the 100 most innovative companies and has branches in different part of the world.

\subsection{Methods of Data Analysis}

This study employed qualitative data, which were analyzed by identifying, examining, and 


\section{Macrothink}

International Journal of Human Resource Studies

ISSN 2162-3058 2020, Vol. 10, No. 3

interpreting patterns and themes in textual data and determining how these themes and patterns help answering the proposed research questions (Siggelkow, 2007). Specifically, this study utilized narrative approach, as per the suggestion of Lichtman (2014, p. 317). According to Lichtman (2014), the narrative approach aims to interpret data by retelling stories that are collated as data and makes emphasizes on data analysis that is characterized by a general (non-detailed) features of coding process.

\section{Results}

Table-3 reported the types of technology-based recruitment and selection approaches adopted by the AMNC and their benefits as per the interviewed HR managers, hiring managers, and employees hired by technology-based recruitment and selection approaches. As shown in Table-3, the overwhelming majority of the interviewees were of the opinions that technology-based recruitment and selection approaches have provided a number of benefits.

Table 3. The types of technology-based recruitment and selection approaches used by the AMNC and their benefits

№ Types of technology-based recruitment and selection approaches

2

$\begin{array}{lll}\text { Recruiting } & * \text { AMNC } & \text { Reduced recruiting \& selection costs } \\ \text { software } & \text { own } & \\ & \text { recruiting } & \text { Increased the number of job applicants } \\ & \text { software } & \end{array}$

Improved the quality of applicants

Streamlined recruiting \& sel. processes

Improved convenience \& flexibility
Do you think these technology-based recruitment and selection approaches provided the following benefits?

$\begin{array}{llll}\text { HR managers } & \text { Hiring } & \begin{array}{l}\text { Emp. hired via } \\ \text { managers }\end{array} & \begin{array}{l}\text { tech.-based rec. \& } \\ \text { sel. approaches }\end{array}\end{array}$

$\begin{array}{ll}\text { *AMNC's } & \text { Reduced recruiting \& selection costs } \\ \text { corporate } & \\ \text { job board } & \text { Increased the number of job applicants } \\ \text { *Commerci } & \\ \text { al job boards } & \text { Improved the quality of applicants }\end{array}$

Streamlined recruiting \& sel. processes

Improved convenience \& flexibility

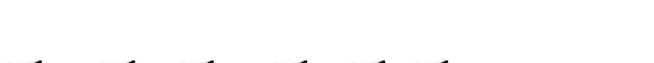


Social media * LinkedIn Reduced recruiting \& selection costs

* Facebook

Increased the number of job applicants

Improved the quality of applicants

Streamlined recruiting \& sel. processes

Improved convenience \& flexibility

Interactive $\quad *$ Skype $\quad$ Reduced recruiting \& selection costs technologies

$$
\begin{aligned}
& \text { Increased the number of job applicants } \\
& \text { Improved the quality of applicants } \\
& \text { Streamlined recruiting \& sel. processes } \\
& \text { Improved convenience \& flexibility }
\end{aligned}
$$
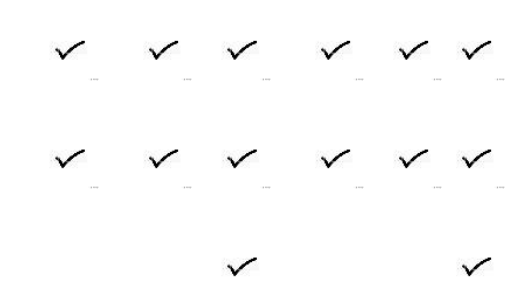

5 Gamification N/A

of recruitment

Source: Interviewed HR managers, hiring managers, and employees hired via technology-based recruitment and selection approaches.

The results of the semi-structured interviews are presented below. In-depth interviews indicated that like most companies, AMNC's recruitment process begins with the identification of a need for a position to be filled by the department manager, which then gains permission from the Executive Vice President to begin the recruitment process. The department manager then decides the details of the position to be filled, the length of the job posting and whether to post the job internally, externally, or both. The posting is then reviewed by the HR professionals, who also add the job overview, responsibilities, and specifications. After the job posting is finalized, it is posted onto the AMNC's careers page. The careers page is the only location that jobseekers can apply for positions with AMNC, although they may be able to find information about job availability within AMNC on many different websites such as Indeed, Monster, Local Job Network, VetJobs, LinkedIn, \& Facebook. The interviewees strongly believed that all the steps of recruitment process have been affected by technology.

In-depth interviews further revealed that the AMNC has a corporate job-board. At the top of AMNC's corporate website, there is a link to the careers page. AMNC's corporate website has three different categories: about us, benefits, and opportunities (careers page). The "opportunities" tab features AMNC's different departments, diversity related values, promotion policy, and video clips of employees' testimonials. Below the "opportunities" tab is the "career search" tab. The "career" tab has a search engine that enables users to look for 
specific job openings. Job applicants can search and filter job openings by zip/postal code and country as well as by job type (full or part-time), department, and job ID and submit their resume online. The "career search" page has an attractive graphics interface for users, which is also user-friendly and is easy to navigate. In-depth interviews showed that AMNC's career site has increased awareness of job availability, which in turn has also increased the number of potential job applicants. The career website has an online job application that is linked to its ATS. Corporate website runs through the entire company and that is where job postings go. Recruitment ends once job applications are received. The job application screening process at AMNC is very consistent throughout the entire company. Each application is submitted to the ATS which is then reviewed by the HR professionals, who also start screening the job application within 48 hours. All the interviewees strongly agreed that all steps of the selection process profoundly impacted by technology. One of the interviewed HR managers noted that,

"AMNC has used different recruiting software. For instance, between 2010 and 2015, it used a recruiting software provided by PreVisor, which was first acquired by SHL and then by CEB and paid about $\$ 200,000$ a year. In 2015, however, it designed its own HR/recruiting software using its own employees and that its 300 IT employees played a critical role in the creation and implementation of the current HR/recruiting software. The HR/recruiting software has been regularly updated and improved based on the new technological development and unique context of AMNC. Since its creation, many new useful and helpful features have been incorporated into the system." (HR manager \#2, personal communication)

The AMNC's marketing team has been using social media channels such as Facebook, Twitter, YouTube, LinkedIn \& Instagram primarily as sales and marketing tools. Recently, however, AMNC has also used social media channels such as LinkedIn and Facebook for recruiting purposes. Its posts \& engagement have been successful with LinkedIn and the Facebook page for Careers. As one of the HR managers noted,

"Since about 58 percent of American Adults are active on Facebook, including 87 percent of those ages 18-29, we started to give more weight to social media channels such as Facebook and LinkedIn for recruiting purposes." (HR manager \#1, personal communication)

Another HR manager also stated that,

"The number of potential applicants who were attracted by social media channels has increased and we never say apply now, but we say what we are about and allow people to self-select if they are interested in the company. Hence, recruiting used to be so direct but now it is more indirect with social media." (HR manager \#2, personal communication)

Interviewed HR manager and hiring manager disclosed that,

"Before the adoption of technology-based recruitment and selection approaches, AMNC had to receive job applications in person or by mail, which led to losing many job applications in the process, selection process was very time consuming and highly unorganized, interview rooms were stacked full of job applicants' information, and hiring manager had their own interview questions and methods. However, since the implementation of the current HR/recruiting system, job application has become completely online, and the entire hiring process has become streamlined, efficient, consistent, and 
simple to use. If a job application is not completed, the HR/recruiting system weeds it out of the system. As a result, AMNC is able to screen so many job applications within short period of time." (HR manager \#2 and hiring manager \#3, personal communication)

Similarly, an interviewed hiring manager also stated that,

"We used to have managers doing everything different, now all managers go through the exact same process. They do not need to think about what to do next because there is a strict process that is not difficult to follow. The flow chart, which is aided by technology, defines their tasks and roles." (Hiring manager \#2, personal communication)

In the words of another interviewed HR manager,

"The AMNC recruited about 3 to 30 applicants per position given the prevailing tight labor market. On average, it also received/screened up to 10,000 job applications per month and that majority of them were recruited through technology-based recruitment and selection approaches. It also provided about 13,000 job offers to internal and external applicants in 2017, although some declined." (HR manager \#3, personal communication)

In-depth interviews with employees hired via technology-based recruitment and selection approaches indicated that, overall, they were satisfied with AMNC's technology-based recruitment and selection approaches. They also underscored that, although they received feedback from the HR professionals and hiring managers during the recruitment and selection processes mainly through an email, they suggested that AMNC should work more at providing prompt feedback at each stage of the recruitment and selection processes through different means of technology. They also noted that although AMNC's career search page looks good and there are some video clips of employees' testimonials, they suggested that AMNC should keep working to make the career search page more attractive, easy to navigate, and user-friendly and add more video clips of employees' testimonials and that video clips should be updated regularly.

\section{Discussion}

The main goal of the current study is to review six technology-based recruitment and selection approaches and discuss the perceptions of the three stakeholders, namely HR managers, hiring managers, and employees hired via technology-based recruitment and selection approaches. The findings of this study indicated that the AMNC had adopted four of the six identified technology-based recruitment and selection approaches. In addition, the overwhelming majority of the interviewees disclosed their high satisfaction of the technology-based recruitment and selection approaches adopted by the AMNC.

Our findings (Table-3) are in line with the findings of prior studies in that technology-based recruitment and selection approaches adopted by AMNC have reduced recruiting and selection costs (Feffer, 2017; Maurer \& Liu, 2007; Ouirdi, Ouirdi, Segers \& Pais, 2016; Tong, 2009); increased the number of job applications received per open job (Chapman \& Webster, 2003; Selden \& Orenstein, 2011); streamlined recruiting and selection processes (Dulebohn \& Johnson, 2013; Sierra-Cedar, 2018); and improved the convenience and flexibility for HR 
professionals, job applicants, and hiring managers (Fleck, 2016; Zielinski, 2016). Unlike most previous studies, however, AMNC has not adopted recruiting software available on the market since 2015. Instead, it has successfully designed and implemented its own $\mathrm{HR} /$ recruiting software compatible with its unique circumstances. It must also be noted that, although AMNC has used many technology-based recruitment and selection approaches (e.g., corporate job board, commercial boards, recruiting software, social media channels, and interactive technologies), it has not yet adopted tools such as HR analytics and gamification of recruitment for recruiting and selection purposes.

An interesting finding of the study is that, although the majority of the AMNC's potential job applicants have been attracted through technology-based recruitment and selection approaches, it still uses traditional recruitment and selection approaches such as job fairs face-to-face recruitment by attending college career fairs and other job fairs in the area. HR professionals often attend job-fairs and other events and encourage jobseekers to apply at AMNC's corporate website. Although HR professionals do not accept resumes or paper job applications at these events, many online job applicants mentioned they became aware of job openings through interaction with HR professionals and employees. Thus, the traditional recruitment and selection approaches are not completely replaced by technology-based recruitment and selection approaches.

This study has some practical implications. Some of the important implications are as follows: First, this study indicated that with the creation of the current HR/recruiting software in 2015, the effectiveness and efficiency of AMNC's recruitment and selection processes have increased for it was compatible with its unique circumstance. Thus, one of the important findings of this study is the role of having an appropriate technology-based recruitment and selection approach. Second, this study uncovered that the AMNC has benefited from the use of social media channels. Thus, in order to exploit the benefits of social media channels, companies should encourage and train HR professionals, hiring managers, and employees on how to use social media on behalf of their company. Such practice can help in improving organizational image and providing a first-hand view of life at the company for jobseekers and customers (Glassdoor, 2016; Vitale, 2016). Third, this study indicated that the AMNC has been attempting to make its corporate job website (careers page) more attractive and easier to navigate, which in turn has increased the number of job applicants. Hence, companies must work to make their job webpages attractive and use more user-friendly options, add an option to add resumes, and options to send questions about job vacancies. As noted by Ngai, Tao, \& Moon (2015), although large companies have deployed corporate career websites, many of them have failed to achieve maximum benefits because they failed to make their career websites attractive and easy to navigate.

\section{Conclusions and Future Research Directions}

This study reveals that the AMNC uses technology-based recruitment and selection approaches such as corporate job-board, commercial job-boards (e.g., Indeed \& Monster), social media (e.g., LinkedIn \& Facebook), recruiting software, and interactive technologies (e.g., video conference). It indicates that technology-based recruitment and selection 
approaches have had a noticeable impact on the overall recruitment and selection processes in general and the three stakeholders in particular. In that respect, this study argues that the use of technology for recruiting and selection purposes is not the matter of choice but is a requirement for the success of any company and concludes that it is no longer a question of whether a company uses technology-based recruitment and selection approaches, but how they are deployed and utilized that matters.

This study also concludes that, although AMNC utilizes technology-based recruitment and selection approaches extensively, it still uses traditional recruitment methods. This indicates that both traditional and technology-based recruitment and selection approaches complement to each other. This study also argues that technology does part of the recruitment and selection processes, in that, while technology plays a significant role in recruiting and selection processes, human intervention or the role of HR professionals and hiring managers is still critical. Thus, the adoption and use of technology for recruitment and selection purposes should be regarded as a decision support tool, not to replace traditional recruitment and selection practices.

This study extends prior studies on technology-based recruitment and selection approaches and practices. This study has merit because, unlike most previous studies, it discussed technology-based recruitment and selection approaches on the eyes of the three stakeholders: HR managers, hiring managers, and employees hired via technology-based recruitment and selection approaches. This study, however, is based on one American multinational company and therefore, its findings may not be generalized. Hence, it would be interesting if future research discusses technology-based recruitment and selection approaches adopted by companies on the eyes of the three main stakeholders using a larger sample size. Moreover, future research should be directed at examining the effects of technology on other HR functions such as training and development, employee performance evaluation, compensation, and employee benefits on the eyes of the HR managers, hiring managers, and employees.

\section{References}

Al-Khanak, S. A. \& Mahmood, N. (2014). Factors influence organization management towards using electronic recruitment strategy. Sains Humanika, 2(2), 47-62.

Allen, D. B., Mahto, R. V., \& Otondo, R. F. (2007). Web-based recruitment: Effects of information, organizational brand, and attitudes toward a web site on applicant attraction. Journal of Applied Psychology, 92(6), 1696-1708.

Barney, J. (1991). Firms resources and sustained competitive advantage. Journal of management, 17(1), 99-120.

Bates, S. (2016). Negative online reviewers: Respond or ignore? HR Magazine, 60(2), 1.

Bersin, J. (2017). Transformative tech: A disruptive a year ahead. HR Magazine 62(1), 29-36.

Bondarouk, T., Parry, E., \& Furtmueller, E. (2017). Electronic HRM: four decades of research on adoption and consequences. International Journal of Human Resource Management, 28(1), 98-131.

Breaugh, J. A. (2013). Employee Recruitment. Annual Review of Psychology, 64, 389-416. 
Buckley, P., Minette, K., Joy, D., \& Michaels, J. (2004). The use of an automated employment recruiting and screening system for temporary professional employees: A case study. Human Resource Management, 43, 233-241.

Campos, R., Arrazola, M., \& Hevia, J. (2017). Finding the right employee online: Determinants of internet recruitment in Spanish firms. Journal of Applied Economics, 50(1), 79-93.

Cappelli, P. (2001). Making the most of on-line recruiting. Harvard Business Review, 79, 139-146.

CareerBuilder. (2017, July 7). Press room: CareerBuilder's 2017 midyear job forecast. Retrieved from http://press.careerbuilder.com/2017-07-07-60-Percent-of-Employers-Plan-to-Hire-Full-time-P ermanent-Employees-in-the-Second-Half-of-2017.I

Chapman, D. S., \& Webster, J. (2003). The use of technologies in the recruiting, screening, and selection processes for job candidates. International Journal of Selection and Assessment, $11,113-120$.

Creswell, J. W. (2007). Qualitative inquiry and research design: Choosing among five approaches (2nd ed.). Thousand Oaks, CA: Sage.

Dearborn, J., \& Swanson, D. (2017). The data driven leader: A powerful approach to delivering measurable business impact through people analytics. New York: John Wiley \& Sons.

Dineen, B. R., \& Allen, D. G. (2013). Internet recruiting 2.0: Shifting paradigms. In K. Y. T. Yu and Daniel M. Cable (Eds.), The Oxford handbook of recruitment (pp. 382-401). New York: Oxford University Press.

Dineen, B. R., \& Noe, R. A. (2009). Effects of customization on application decisions and applicant pool characteristics in a Web-based recruitment context. Journal of Applied Psychology, 94, 224-234.

Eisenhardt, K. M. (1989). Building theories from case study research. Academy of Management Review, 14(4), 532-550.

El Ouirdi, M., El Ouirdi, A., Segers, J., \& Pais, I. (2016). Technology adoption in employee recruitment: The case of social media in Central and Eastern Europe. Computers in Human Behavior, 57, 240-249.

Emerald. (2013). Recruitment goes virtual: Use web-based technology intelligently for best results in recruitment. Human Resource Management International Digest, 21(3), 19-21.

Ezzy, D. (2002). Qualitative analysis: Practice and innovation. London, Routledge.

Feffer, M. (2017). Emphasize efficiency: HR professionals can play a key role in increasing better business practices. HR Magazine, 62(4), 55-60.

Fleck, C. (2016). An algorithm for success: People analytics are becoming as important as people skills in making insightful workforce decisions. HR Magazine. 60(2), 130-135.

Glassdoor (2016, July 14). Top HR statistics: The latest stats for HR \& recruiting pros. Retrieved from https://www.glassdoor.com/employers/popular-topics/hr-stats.htm 


\section{Macrothink}

International Journal of Human Resource Studies ISSN 2162-3058 2020, Vol. 10, No. 3

Gravili, G. (2003). Electronic recruiting: Trends in the Italian market. EBS Review, 32-142.

Heneman, H. G., Judge, T. A., \& Kammeyer-Mueller, J. (2019). Staffing organizations (9th ed.). NY: McGraw-Hill Irwin.

Holm, A. (2010). The effect of e-recruitment on the recruitment process: Evidence from case studies of three Danish MNCs. In Poceedings of the 3rd European academic workshop on electronic human resource management (pp. 91-111).

Hubbard, M. A., \& Loos, A. T. (2013). Academic library participation in recruitment and retention initiatives. Reference Services Review, 41(2), 157-181.

Jackson, H. G. (2016). Three principles of the 21st century workplace. HR Magazine, 60(6), 4.

Johnson, R. D., \& Gueutal, H. G. (2011). Transforming HR through technology: The use of eHR and human resource information systems in organizations. SHRM Effective Practices Guidelines Series, SHRM, Alexandria, Virginia.

Kavanagh, M. J., \& Johnson, R. D. (2018). Human resource information systems: Basics, applications, and future directions (4th ed.). Thousand Oaks: Saga Publications, Inc.

Kuncel, N. R., Klieger, D. M., \& Ones, D. S. (2014). In hiring, algorithms beat instinct. Harvard Business Review, 92, 32.

Lavelle, L. (2003). Coming next: A war for talent. Business Week. p. 1.

Lepak, D., \& Gowan, M. (2020). Human resource management: Managing employees for competitive advantage ( $4^{\text {th }}$ ed.). Chicago: Chicago Business Press.

Lichtman, M. (2014). Qualitative research for the social sciences. Thousand Oaks, California: Sage.

Marler, J. H., \& Parry, E. (2015). Human resource management, strategic involvement and e-HRM technology. The International Journal of Human Resource Management, 27(19), 2233-2253.

Mathis, R. L., Jackson, J. H., Valentine, S., \& Meglich, P. A. (2017). Human resource management $\left(15^{\text {th }}\right.$ ed.). New York: Cengage.

Maurer, R. (2016). 5 big recruiting trends. HR Magazine, 61(3), 7.

Maurer, R. (2017). Strategic talent sourcing: To maximize recruiting efforts, all companies must become tech companies. HR Magazine, 62(4), 70-73.

Maurer, S. D., \& Lui, Y. (2007). Developing e-recruiting websites: Insights for managers from marketers. Business Horizons, 50(4), 305-14.

Melanthiou, Y., Pavlou, F., \& Constantinou, E. (2015). The use of social network sites as an e-recruitment tool. Journal of Transnational Management, 20(1), 31-49.

Ngai, E. W. T., Moon, K. K., Lam, S. S., Chin, E. S. K., \& Tao, S. S. C. (2015). Social media models, technologies, and applications: An academic review and case study. Industrial Management \& Data Systems, 115(5), 769-802.

Ollington, N., Gibb, J., \& Harcourt, M. (2013). Online social networks: An emergent recruiter 
tool for attracting and screening. Personnel Review, 42(3), 248-265.

Orso, M. E., \& Rodriguez, S. C. (2017). The compliance risks of I-9 software. HR Magazine, 64(1), 83-84.

Pandre, S. (2011). E-recruitment creates order out of chaos at SAT Telecom. Human Resource Management International Digest, 9(3), 21-23.

Parry, E., \& Wilson, H. (2009). Factors influencing the adoption of online recruitment. Personnel Review, 38(6), 655-673.

Pfieffelmann, B., Wagner, S. H., \& Libkuman, T. (2010). Recruiting on corporate web sites: Perceptions of fit and attraction. International Journal of Selection and Assessment, 18, 40-47.

Phillips. J. M. (2020). Strategic staffing (4 ${ }^{\text {th }}$ ed.). Chicago: Chicago Business Press.

Ployhart, R. E. (2006). Staffing in the 21st century: New challenges and strategic opportunities. Journal of Management, 32(6), 868-897.

Schreurs, B., \& Syed, F. (2011). Battling the war for talent: An application in a military context. Career Development International, 16(1), 36-59.

Scorza, J. (2017). Stay in touch, jobseekers say. HR Magazine, 62(5), 16.

Shah, T. (2004). Retailers sometimes turn to different means of screening applicants. Knight Riddle Tribune Business News, p.1.

SHRM (2016). Talent acquisition: Selection. Alexandria, VA: SHRM.

SHRM (2017). SHRM survey findings: Using social media for talent acquisition. Alexandria, VA: SHRM.

Sierra-Cedar (2018, December 20). 2017-2018 HR systems survey 20th annual edition. Retrieved from https://www.sierra-cedar.com/wp-content/uploads/sites/12/2018/01/Sierra-Cedar_2017-2018_ HRSystemsSurvey_WhitePaper.pdf

Siggelkow, N. (2007). Persuasion with case studies. Academy of Management Journal, 50, 20-24.

Singh, L., \& Narang, L. (2008). Behavioral revelation concerning e-recruitment. ICFAI Journal of Organizational Behavior, 7, 45-53.

Stone, D. L., Deadrick, D. L., Lukaszewski, K. M., Johnson, R. (2015). The influence of technology on the future of human resource management. Human Resource Management Review, 25(2), 216-231.

Stone, D. L.,\& Lukaszewski, K. M.(2009). An expanded model of the factors affecting the acceptance and effectiveness of electronic human resource management systems. Human Resource Management Review, 19(2), 134-143.

Tessema, M. T., Gok, K., Ngoma, A., Tesfayohannes, M., \& Fernando, G. V. (2017). Staffing system management: Evidence from Singapore. International Journal of Human Resource Studies, 7(2), 136-154. 


\section{Macrothink}

International Journal of Human Resource Studies

ISSN 2162-3058 2020, Vol. 10, No. 3

Tong, D. Y. K. (2009). A Study of e-recruitment technology adoption in Malaysia. Industrial Management \& Data Systems, 102(9), 81-90.

Tufts, S. H., Jacobson, W. S., \& Stevens, M. S. (2014). Social media and local government human resource practices. Review of Public Personnel Administration, 35(2), 193-207.

Vitale, S. (2016). Social recruiting: What you need to know for success. HR Magazine, 61(4), 14.

Weber, L. (2012). Your résumé vs. oblivion: inundated companies resort to software to sift job applications for right skills. Wall Street Journal, 7-9.

Wright, A. D. (2018). $6 \mathrm{HR}$ tech trends for 2018. HR Magazine, 63(1), 62-63.

Yin, R. K. (1994). Case study research: Design and methods (2nd ed.). Newbury Park, CA: Sage Publications.

Zielinski, D. (2015). The gamification of recruitment: Virtual games are scoring points for companies' talent acquisition strategies. HR Magazine, 60(6), 40-44.

\section{Copyright Disclaimer}

Copyright for this article is retained by the author(s), with first publication rights granted to the journal.

This is an open-access article distributed under the terms and conditions of the Creative Commons Attribution license (http://creativecommons.org/licenses/by/4.0/). 